\title{
HUBUNGAN KARAKTERISTIK MASYARAKAT DENGAN KEJADIAN COVID 19 DI DESA PAYUNG KECAMATAN WELERI
}

\author{
Sri Hesthi Sonyo Rini ${ }^{1}$, Sulastri ${ }^{2}$ \\ ${ }^{1,2}$ STIKES Muhammadiyah Kendal \\ Email: hesthisonyo84@gmail.com
}

\begin{abstract}
ABSTRAK
Pada saat ini terdapat masalah kesehatan yang menjadi sorotan dan perhatian dunia yaitu penyakit Covid-19. Penyakit ini disebabkan oleh virus yang bernama Corona Virus Disease - 19 atau yang lebih popular dengan istilah Covid-19. Menanggapi hal tersebut pemerintah telah mengeluarkan kebijakan atau peraturan untuk mencegah pertambahan jumlah kasus yaitu berupa protokol kesehatan penanganan Covid-19. pemerintah telah menerbitkan protokol kesehatan penanganan Covid-19 yaitu diantaranya protokol kesehatan, perbatasan, komunikasi, area pendidikan, dan area publik dan transportasi, termasuk juga didalamnya yaitu kebijakan berupa pemberlakuan Pembatasan Sosial Berskala Besar (PSBB) dibeberapa wilayah yang ada di Indonesia.. Tujuan dari penelitian ini bertujuan untuk mengetahui hubungan karakteristik masyarakat dengan kejadian covid 19 di desa Payung Kecamatan Weleri.

Desain Penelitian adalah deskriptif korelatif dengan Teknik pengambilan sampel menggunakan Simple random sampling dengan sampel sebanyak 58 responden. Analisis statistic menggunakan chi square. Dari hasil penelitian didapatkan ada hubungan usia, jenis kelamin, pendidikan dan pekerjaan dengan kejadian Covid-19 di desa Payung Kecamatan Weleri dengan nilai $p$ value $<0,05$.
\end{abstract}

Kata kunci: karakeristik masyarakat, kejadian covid-19 


\title{
CORRELATION OF COMMUNITY CHARACTERISTICS WITH THE EVENT OF COVID 19 IN PAYUNG VILLAGE, WELERI DISTRICT
}

\begin{abstract}
At this time there is a health problem that is in the spotlight and attention of the world, namely the Covid-19 disease. This disease is caused by a virus called Corona Virus Disease - 19 or more popularly known as Covid-19. In response to this, the government has issued a policy or regulation to prevent the increase in the number of cases, namely in the form of a health protocol for handling Covid-19. The government has issued health protocols for handling Covid-19, including health protocols, borders, communications, education areas, and public and transportation areas, including policies in the form of implementing Large-Scale Social Restrictions (PSBB) in several areas in Indonesia. This study aims to determine the relationship between community characteristics and the incidence of covid 19 in Payung Village, Weleri District.

Research design is descriptive correlation with sampling technique using simple random sampling with a sample of 58 respondents. Statistical analysis using chi square. From the results of the study, it was found that there was a relationship between age, gender, education and occupation with the incidence of Covid-19 in Payung Village, Weleri District with a $p$ value $<0.05$.
\end{abstract}

Keywords: Community characteristics, The incidence of covid-19

\section{PENDAHULUAN}

Pada saat ini terdapat masalah kesehatan yang menjadi sorotan dan perhatian dunia yaitu penyakit Covid-19. Penyakit ini disebabkan oleh virus yang bernama Corona Virus Disease - 19 atau yang lebih popular dengan istilah Covid19. Coronavirus Disease 2019 (Covid-19) adalah penyakit menular yang disebabkan oleh Severe Acute Respiratory Syndrome Coronavirus 2 (SARS-CoV-2). SARSCoV-2 merupakan coronavirus jenis baru yang belum pernah diidentifikasi sebelumnya pada manusia. Ada setidaknya dua jenis coronavirus yang diketahui menyebabkan penyakit yang menimbulkan gejala beratseperti Middle East Respiratory Syndrome (MERS) dan Severe Acute Respiratory Syndrome (SARS). Tanda dan gejala umum infeksi Covid-19 antara lain gejala gangguan pernafasan akut seperti demam, batuk dan sesak napas. Masa inkubasi rata-rata 5-6 hari dengan masa inkubasi terpanjang 14 hari. Pada kasus Covid-19 yang berat 
dapat menyebabkan pneumonia, sindrom pernafasan akut, gagal ginjal, dan bahkan kematian (Kementrian Kesehatan RI, 2020).

Corona Virus Disease - 19 atau yang lebih populer dengan istilah COVID-19 telah ditetapkan oleh WHO (World Health Organization) atau Badan Kesehatan Dunia sebagai Kedaruratan Kesehatan Masyarakat yang Meresahkan Dunia (KMMD) pada tanggal 30 Januari 2020 dan akhirnya ditetapkan sebagai Pandemi pada tanggal 11 Maret 2020 (Keliat et al., 2015). Angka kejadian Covid-19 di dunia setiap harinya selalu bertambah (WHO, 2020). Berdasarkan data yang didapat pada tanggal 20 september 2020, total kasus covid-19 didunia sebanyak 30,9 juta kasus dengan jumlah kasus meninggal sebanyak 960.830 orang. Amerika merupakan negara tertinggi yang menderita Covid-19 dengan jumlah kasus positif sebesar 6.966.356 orang dan 203.822 orang meninggal (Lestari, 2020)

Di Indonesia, kasus covid-19 pertama kali dikonfirmasi pada tanggal 02 Maret 2020 sejumlah dua kasus . Pada bulan Mei 2020, angka kematian juga masih terus terjadi walaupun diimbangi dengan jumlah kesembuhan pasien. Secara global kasus covid-19 sebanyak
4.170.424 kasus dengan 287.399 kasus kematian (WHO, 2020). Di Indonesia, penambahan jumlah kasus terkonfirmasi terus meningkat, dimana pada Bulan Mei masih berada pada angka 10.551 kasus dengan 800 orang meninggal dunia (Nashrullah, 2020) akan tetapi hingga 16 Juni 2020 kasus bertambah cukup signifikan menjadi berjumlah 40.400 kasus dengan jumlah kematian sebanyak 2231 kematian (Rahayu Oktavia Asy'ari, 2020).

Menanggapi hal tersebut pemerintah telah mengeluarkan kebijakan atau peraturan untuk mencegah pertambahan jumlah kasus yaitu berupa protokol kesehatan penanganan Covid-19 (Yuliana, 2020). Menurut Kementerian Kesehatan RI (2020), pemerintah telah menerbitkan protokol kesehatan penanganan Covid-19 yaitu diantaranya protokol kesehatan, perbatasan, komunikasi, area pendidikan, dan area publik dan transportasi, termasuk juga didalamnya yaitu kebijakan berupa pemberlakuan Pembatasan Sosial Berskala Besar (PSBB) dibeberapa wilayah yang ada di Indonesia (Deng et al., 2020).

Penularan melalui kontak dekat dan droplet, bukan melalui transmisi udara. Orang yang berisiko terinfeksi adalah 
yang berhubungan dekat dengan orang yang positif covid-19. Tindakan pencegahan merupakan kunci penerapan di pelayanan kesehatan dan masyarakat. Langkah pencegahan di masyarakat adalah dengan menjaga kebersihan tangan menggunakan hand sanitizerjika tangan tidak terlihat kotor. Cuci tangan dengan sabun jika tangan terlihat kotor. Menghindari menyentuh mata, hidung dan mulut.Dan menerapkan etika batuk atau bersin dengan menutup hidung dan mulut dengan lengan atas bagian dalam.Memakai masker dan menjaga jarak (minimal 1 meter) dari orang lain. Melakukan komunikasi risiko penyakit dan pemberdayaan masyarakat untuk meningkatkan pengetahuan. Penyakit komorbid hipertensi dan diabetes melitus, jenis kelamin laki-laki, dan perokok aktif merupakan faktor risiko dari penyakit Covid-19 (World Health Organization, 2020).

Tanda dan gejala umum infeksi Covid-19 antara lain gejala gangguan pernapasan akut seperti demam, batuk dan sesak napas. Masa inkubasi rata-rata 5-6 hari dengan masa inkubasi terpanjang 14 hari. Pada kasus COVID-19 yang berat dapat menyebabkan pneumonia, sindrom pernapasan akut, gagal ginjal, dan bahkan kematian. Tanda-tanda dan gejala klinis yang dilaporkan pada sebagian besar kasus adalah demam, dengan beberapa kasus mengalami kesulitan bernapas, dan hasil rontgen menunjukkan infiltrat pneumonia luas di kedua paru (Mujani \& Irvani, 2020)

Banyak nya kasus covid-19 dari anak-anak sampai orang tua, bekerja dan tidak bekerja, berjenis kelamin laki-laki dan perempuan serta orang yang berpendidikan dan tidak berpendidikan akan terkena covid-19 di desa payung membuat peneliti tertarik untuk melakukan penelitian dengan judul hubungan karakteristik masyarakat dengan kejadian covid 19 di desa Payung Kecamatan Weleri

\section{METODE}

Metode penelitian kuantitatif, Desain penelitian deskriptif korelatif dengan Teknik pengambilan sampel menggunakan Simple random sampling dengan sampel sebanyak 58 responden. Penelitian ini dilakukann pada bulan Januari-Februari 2021, di desa Payung Kecamatan Weleri Kabupaten Kendal. 
HASIL

Tabel 1 Deskripsi usia, jenis kelamin, pendidikan, pekerjaan di Desa Payung Kecamatan Weleri $(n=58)$ bulan Februari 2021

\begin{tabular}{lcc}
\hline Usia Responden & Frekuensi (f) & Presentase (\%) \\
\hline 17-39 tahun & 26 & 44,8 \\
40-60 tahun & 32 & 55,2 \\
\hline Jenis kelamin & & \\
\hline Laki-laki & 28 & 48,3 \\
Perempuan & 30 & 51,7 \\
\hline Pendidikan & & \\
\hline SD & 26 & 44,8 \\
SMP & 13 & 22,4 \\
SMA & 11 & 19,0 \\
PT & 8 & 13,8 \\
\hline Pekerjaan & & \\
\hline Bekerja & 19 & 32,8 \\
Tidak Bekerja & 26 & 44,8 \\
Pelajar/Mahasiswa & 13 & 22,4 \\
\hline Total & 58 & 100,0 \\
\hline
\end{tabular}

Tabel 2. Distribusi frekuensi kejadian covid-19 di Desa Payung Kecamatan Weleri $(\mathrm{n}=58)$ bulan Februari 2021

\begin{tabular}{lcc}
\hline Kejadian Covid-19 & Frekuensi (f) & Presentase (\%) \\
\hline Covid & 28 & 48,3 \\
Tidak covid & 30 & 51,7 \\
\hline Total & 58 & 100,0 \\
\hline
\end{tabular}

Tabel 3. Hubungan usia dengan kejadian covid -19 di Desa Payung Kecamatan Weleri $(n=58)$ bulan Februari 2021

\begin{tabular}{lcccc}
\hline & \multicolumn{2}{c}{ Kejadian Covid } & Total & P value \\
\cline { 2 - 4 } Usia & $\begin{array}{c}\text { Covid } \\
\text { Frekuensi }(\%)\end{array}$ & $\begin{array}{c}\text { Tidak covid } \\
\text { Frekuensi }(\%)\end{array}$ & \\
\hline $17-39$ tahun & $7(12,1)$ & $19(32,8)$ & $26(44,8)$ & 0,003 \\
$40-60$ tahun & $21(36,2)$ & $11(19,0)$ & $32(55,2)$ & \\
\hline Total & $28(48,3)$ & $30(51,7)$ & $58(100)$ & \\
\hline
\end{tabular}


Tabel 4. Hubungan jenis kelamin dengan kejadian covid -19 di Desa Payung Kecamatan Weleri $(n=58)$ bulan Februari 2021

\begin{tabular}{lcccc}
\hline \multirow{2}{*}{ Jenis kelamin } & \multicolumn{2}{c}{ Kejadian Covid } & Total & P value \\
\cline { 2 - 4 } & $\begin{array}{c}\text { Covid } \\
\text { Frekuensi }(\%)\end{array}$ & $\begin{array}{c}\text { Tidak covid } \\
\text { Frekuensi }(\%)\end{array}$ & & \\
\hline Laki-laki & $9(15,5)$ & $19(32,8)$ & $28(48,3)$ & 0,018 \\
Perempuan & $19(32,8)$ & $11(19,0)$ & $30(51,7)$ & \\
\hline Total & $28(48,3)$ & $30(51,7)$ & $58(100)$ & \\
\hline
\end{tabular}

Tabel 5. Hubungan pendidikan dengan kejadian covid -19 di Desa Payung Kecamatan Weleri $(n=58)$ bulan Februari 2021

\begin{tabular}{lcccc}
\hline \multirow{2}{*}{ Pendidikan } & \multicolumn{2}{c}{ Kejadian Covid } & Total & P value \\
\cline { 2 - 4 } & $\begin{array}{c}\text { Covid } \\
\text { Frekuensi }(\%)\end{array}$ & $\begin{array}{c}\text { Tidak covid } \\
\text { Frekuensi }(\%)\end{array}$ & & \\
\hline SD & $19(32,8)$ & $7(12,1)$ & $26(44.8)$ & 0,002 \\
SMP & $6(10,3)$ & $7(12,1)$ & $13(22.4)$ & \\
SMA & $2(3,4)$ & $9(15,5)$ & $11(19,0)$ & \\
PT & $1(1,7)$ & $7(12,1)$ & $8(13,8)$ & \\
\hline Total & $28(48,3)$ & $30(51,7)$ & $58(100)$ & \\
\hline
\end{tabular}

Tabel 6. Hubungan pendidikan dengan kejadian covid -19 di Desa Payung Kecamatan Weleri $(n=58)$ bulan Februari 2021

\begin{tabular}{lcccc}
\hline \multirow{2}{*}{ Pekerjaan } & \multicolumn{2}{c}{ Kejadian Covid } & Total & P value \\
\cline { 2 - 4 } & $\begin{array}{c}\text { Covid } \\
\text { Frekuensi }(\%)\end{array}$ & $\begin{array}{c}\text { Tidak covid } \\
\text { Frekuensi }(\%)\end{array}$ & \\
\hline Bekerja & $8(13,8)$ & $11(19,0)$ & $19(32,8)$ & 0,005 \\
Tidak bekerja & $18(31,0)$ & $8(13,8)$ & $26(44,8)$ & \\
Pelajar/Mahasiswa & $2(3,4)$ & $11(19,0)$ & $13(22,4)$ & \\
\hline Total & $28(48,3)$ & $30(51,7)$ & $58(100)$ & \\
\hline
\end{tabular}

\section{PEMBAHASAN}

\section{Usia}

Hasil penelitian menunjukkan mayoritas responden berusia antara 40-60 tahun sebanyak $32(55,2 \%)$.
Menurut (Notoatmodjo, 2012) usia adalah bilangan tahun terhitung sejak lahir sampai dengan tahun terakhir seseorang melakukan aktivitas. Usia dewasa menengah, dimana usia ini 
dianggap cukup matang dalam pengalaman hidup dan kematangan jiwanya. Menurut (Notoatmodjo, 2012) usia yang dianggap optimal dalam mengambil keputusan adalah usia yang diatas umur 20 tahun. Usia 40-60 tahun rentan terkena covid-19 karena aktivitasnya yang tinggi, bekerja dan bersosialisasi.

Siagian (2018) mengemukakan bahwa semakin bertambah usia seseorang, maka semakin mampu menunjukkan kematangan jiwa, semakin bijaksana dalam mengambil keputusan, mampu berpikir rasional dan mampu mengendalikan emosi dan makin toleran terhadap orang lain. Usia merupakan salah satu faktor internal yang berkontribusi terhadap timbulnya kepatuhan dalam prokokoler covid-19.

Faktor umur erat kaitannya dengan covid-19 karena orang yang lanjut usia adanya proses degeneratif anatomi dan fisiologi tubuh sehingga rentan terhadap penyakit, imunitas yang menurun, ditambah seseorang yang mengidap penyakit penyerta akan menyebabkan kondisi tubuhnya lemah sehingga mudah terinfeksi covid-19 (Rosyanti \& Hadi, 2020)

\section{Jenis kelamin}

Hasil penelitian menunjukkan mayoritas responden berjenis kelamin perempuan sebanyak $30(51,7 \%)$. Jenis kelamin adalah perbedaan seks yang didapat sejak lahir yang dibedakan antara laki-laki dan perempuan. Baik pria maupun wanita memiliki resiko terjadinya covid-19

Meskipun hasil penelitian menunjukkan perempuan yang terinfeksi lebih banyak daripada laki-laki namun perbedaan ini tidak berarti setelah dianalisa secara statistik. Hal ini tidak sesuai dengan literatur yang mengatakan bahwa laki-laki lebih berpeluang terinfeksi daripada perempuan. Berdasarkan studi meta analisis yang menghubungkan jenis kelamin dengan risiko infeksi covid-19 diketahui bahwa laki-laki $28 \%$ lebih berisiko terinfeksi dibandingkan dengan perempuan. Sebanding dengan hubungan jenis kelamin terhadap mortalitas yang menunjukkan bahwa laki-laki lebih berisiko mengalami kematian 1,86\% dibandingkan dengan wanita (Susilo et al., 2020). 
Laki-laki diketahui memiliki ekspresi ACE2 yang lebih tinggi, hal ini terkait hormon seksual yang menyebabkan lakilaki lebih berisiko untuk terinfeksi SARS-CoV-2. Ekspresi ACE2 dikode oleh gen yang terdapat pada kromosom $\mathrm{X}$, perempuan merupakan heterozigot sedangkan laki- laki homozigot, sehingga berpotensi meningkatkan ekspresor ACE2. Infeksi SARS-CoV-2 dan beberapa gejala klinis lainnya mampu dinetralkan karena perempuan membawa alel $\mathrm{X}$ heterozigot yang disebut diamorfisme seksual (Suni, 2020).

Hasil penelitian tidak sesuai dengan literatur bisa dikarenakan ketidakseimbangan jumlah sampel antara jenis kelamin laki-laki dan perempuan yang terlibat dalam penelitian ini. Karena berdasarkan data jumlah laki-laki yang menjadi sampel penelitian lebih sedikit dibandingkan dengan perempuan (Sitepu \& Simanungkalit, 2021).

\section{Pendidikan}

Hasil penelitian menunjukkan sebagian besar responden pendidikan SD sebanyak 26 (44,8\%). Menurut (Notoatmodjo, 2012) semakin tinggi tingkat pendidikan maka semakin mudah seseorang menerima hal baru dan akan mudah menyesuaikan diri. Tingkat pendidikan seseorang atau individu akan berpengaruh terhadap kemampuan berfikir, semakin tinggi tingkat pendidikan akan semakin mudah berfikir secara rasional dan menangkap informasi baru termasuk dalam menguraikan masalah baru.

Secara teori, tingkat pendidikan seseorang akan mempengaruhi tingkat pengetahuannya. Jika tingkat pendidikan dan pengetahuan baik, maka perilaku juga akan baik. Penelitian ini juga sejalan dengan penelitian yang dilakukan oleh (Diva Putra et al., 2020) yang meneliti pada masyarakat China sebagai tempat awal ditemukannya Virus corona ini juga memiliki pengetahuan dan perilaku yang baik dan positif. Hal ini juga dihubungkan dengan pengalaman masyarakat China menghadapi wabah SARS pada Tahun 2000-an.

\section{Pekerjaan}

Hasil penelitian menunjukkan sebagian besar responden tidak bekerja sebanyak 26 (44,8\%). Bekerja atau tidak bekerja menjadi penyebab terjadinya covid-19 seperti penelitian yang dilakukan oleh (Susilo, 2020), menunjukkan bahwa responden yang terkonformasi covid-19 sebagian besar tidak bekerja yaitu 33 orang $(70,2 \%)$. 
Covid-19 ditransmisikan dari orang yang bergejala kepada orang yang melakukan kontak melalui percikan pernapasan, kontak langsung dengan orang yang terinfeksi, atau melalui kontak dengan benda yang terkontaminasi. Studi klinis dan virologi yang telah mengumpulkan sampel biologis berulang dari pasien yang terkonfirmasi positif, memberikan bukti bahwa penyebaran Sars-CoV-2 tertinggi di saluran pernapasan atas (hidung dan tenggorokan). Presentasi klinis Covid19 adalah demam, batuk nonproduktif, dan gangguan pernafasan yang umumnya terjadi pada orang dewasa dibandingkan pada anak-anak (Putra et al., 2020). Sehingga orang bekerja, tidak bekerja dan pelajar bisa terkonfirmasi covid-19 (Jakobsson et al., 2020).

\section{Kejadian Covid-19}

Hasil penelitian menunjukkan mayoritas responden mayoritas responden tidak terkonfirmasi covid19 sebanyak $30(51,7 \%)$ dan sebagian kecil terkonfirmasi covid-19 sebanyak 28 (48,3\%). Covid-19 merupakan virus yang dapat menyebar, salah satunya melalui droplet yang keluar pada saat bersin dan batuk. Orang yang memiliki riwayat kontak erat dengan pasien covid-19 beresiko lebih tinggi untuk terinfeksi penyakit tersebut. Patogenesis covid-19 masih belum diketahui secara pasti, pada manusia covid-19 terutama menginfeksi sel-sel pada saluran pernapasan yang melapisi alveoli dengan cara berikatan dengan reseptor-reseptor kemudian masuk ke dalam sel. Pasien yang terinfeksi covid-19 sebagian besar mengalami gejala gangguan sistem pernapasan seperti batuk, bersin, sesak nafas dan disertai demam (Chatterjee et al., 2020).

Host penyakit ini adalah manusia terutama kelompok yang rentan atau berisiko serta imunitasnya rendah. Karakteristik pejamu dapat dipengaruhi oleh berbagai faktor status gizi, imunitas. Environment penyakit ini adalah lingkungan yaitu lingkungan fisik seperti sanitasi lingkungan yang buruk, lingkungan biologi contohnya kepadatan penduduk, virulensi virus, lingkungan sosial budaya seperti perilaku, lingkungan ekonomi, politik. Faktor risiko terbagi menjadi faktor risiko yang tidak dapat diubah seperti umur, jenis kelamin, ras, suku, genetik 
termasuk adanya kasus pneumonia yang serius yang sebelumnya belum teridentifikasi etiologinya

\section{Hubungan usia dengan kejadian} covid $\mathbf{- 1 9}$

Hasil penelitian menunjukkan usia responden 40-60 tahun dengan kejadian covid sebanyak 21 orang (36,2\%). Hasil perhitungan menggunakan chi square didapatkan nilai $\mathrm{p}$ value $0,003 \quad(\mathrm{P}<0,05)$ menunjukkan ada hubungan usia dengan kejadian Covid di desa Payung Kecamatan Weleri yang berarti $\mathrm{Ha}$ diterima Ho di tolak.

Faktor usia erat kaitannya dengan covid 19 karena orang yang lanjut usia adanya proses degeneratif anatomi dan fisiologi tubuh sehingga rentan terhadap penyakit, imunitas yang menurun, ditambah seseorang yang mengidap penyakit penyerta akan menyebabkan kondisi tubuhnya lemah sehingga mudah terinfeksi covid 19. Selain itu faktor usia yang lanjut menyebabkan kelalaian dalam menjaga protokol covid 19 sehingga meningkatkan risiko covid 19 (Chatterjee et al., 2020).

Menurut (Chatterjee et al., 2020) menyatakan bahwa faktor umur berisiko covid 19 dikarenakan orang dengan usia lanjut ditambah dengan menderita penyakit-penyakit komorbid covid 19 seperti hipertensi. Pada penelitian ini responden terbanyak ada pada rentang usia 40-60 tahun tahun yang berjumlah 21 responden, hal ini menunjukkan usia tersebut adalah usia produktif. Pada usia produktif, kemungkinan untuk mendapatkan Covid-19 akan lebih besar, hal ini dikarenakan mobilitas dan aktifitas yang tinggi di luar rumah. Frekuensi dan interaksi sosial kelompok produktif juga lebih tinggi. Hal yang sama juga diungkapkan oleh CSIS bahwa transmisi infeksi berasal dari kelompok dengan mobilitas yang relatif tinggi, yaitu kelompok usia yang relatif muda. Penyebaran Covid19 di Italia telah menyerang setiap kelompok usia. Pada awalnya, sebagian besar kasus yang tercatat terjadi di kalangan lansia, tetapi seiring penyebaran virus Corona,orang yang lebih muda terjangkit dalam jumlah yang lebih besar (Wu \& McGoogan, 2020)

\section{Hubungan jenis kelamin dengan kejadian covid -19}

Hasil penelitian menunjukkan jenis kelamin perempuan dengan terjadi covid -19 sebanyak 19 orang (32,8\%). 
Hasil perhitungan menggunakan chi square didapatkan nilai $p$ value 0,018 $(\mathrm{P}<0,05)$ menunjukkan ada hubungan jenis kelamin dengan kejadian covid 19 di Desa Payung Kecamatan Weleri yang berarti Ha diterima Ho di tolak.

Meskipun hasil penelitian menunjukkan perempuan yang terinfeksi lebih banyak daripada lakilaki namun perbedaan ini tidak berarti setelah dianalisa secara statistik. Hal ini tidak sesuai dengan literatur yang mengatakan bahwa laki-laki lebih berpeluang terinfeksi daripada perempuan. Berdasarkan studi meta analisis yang menghubungkan jenis kelamin dengan risiko infeksi covid19 diketahui bahwa laki-laki 28\% lebih berisiko terinfeksi dibandingkan dengan perempuan. Sebanding dengan hubungan jenis kelamin terhadap mortalitas yang menunjukkan bahwa laki-laki lebih berisiko mengalami kematian 1,86\% dibandingkan dengan wanita.

Laki-laki diketahui memiliki ekspresi ACE2 yang lebih tinggi, hal ini terkait hormon seksual yang menyebabkan laki-laki lebih berisiko untuk terinfeksi SARS-CoV-2. Ekspresi ACE2 dikode oleh gen yang terdapat pada kromosom $\mathrm{X}$, perempuan merupakan heterozigot sedangkan laki- laki homozigot, sehingga berpotensi meningkatkan ekspresor ACE2. Infeksi SARS-CoV2 dan beberapa gejala klinis lainnya mampu dinetralkan karena perempuan membawa alel $\mathrm{X}$ heterozigot yang disebut diamorfisme seksual.

Selain itu, pada variabel lainnya ditemukan bahwa ada hubungan yang signifikan antara jenis kelamin dengan pengetahuan masyarakat di Kalimantan Selatan mengenai pencegahan Covid-19. Berdasarkan hasil penelitian, dapat disimpulkan bahwa masyarakat dengan jenis kelamin perempuan cenderung memiliki pengetahuan yang lebih baik tentang pencegahan Covid-19 jika dibandingkan dengan laki-laki. Hal ini disebabkan karena masyarakat dengan jenis kelamin perempuan memiliki lebih banyak waktu untuk membaca atau berdiskusi dengan lingkungannya terkait pencegahan Covid-19.

\section{Hubungan pendidikan dengan kejadian covid -19}

Hasil penelitian menunjukkan responden yang mempunyai pendidikan SD dengan kejadian covid19 sebanyak 19 orang (32,8\%). Hasil perhitungan menggunakan chi square 
didapatkan nilai $\mathrm{p}$ value 0,002 $(\mathrm{P}<0,05)$ menunjukkan ada antara pendidikan dengan kejadian Covid di desa Payung Kecamatan Weleri yang berarti Ha diterima Ho di tolak. Pasien yang berpendidikan SD banyak yang terkonfirmasi covid-19 hal ini dikarenakan pasien tidak melakukan atau menjalankan prokol kesehatan yang meliputi $3 \mathrm{M}$ yaitu memakai masker, mencuci tangan dan menjaga jarak (Varghese et al., 2020).

Masyarakat yang berpendidikan SD sulit untuk menerima informasi terkait covid-19. Secara teori, tingkat pendidikan seseorang akan mempengaruhi tingkat pengetahuannya. Jika tingkat pendidikan dan pengetahuan baik, maka perilaku juga akan baik. Penelitian ini juga sejalan dengan penelitian yang dilakukan oleh (Zhong, 2020) yang meneliti pada masyarakat China sebagai tempat awal ditemukannya Virus corona ini juga memiliki pengetahuan dan perilaku yang baik dan positif. Hal ini juga dihubungkan dengan pengalaman masyarakat China menghadapi wabah SARS pada Tahun 2000-an.

Konsep dasar pendidikan adalah suatu proses belajar, dimana dalam suatu proses belajar itu terjadi proses pertumbuhan, perkembangan dan perubahan kearah yang lebih matang pada diri individu, kelompok dan masyarakat (Pratama \& Mulyati, 2020). Dictionary Of Education menyebutkan bahwa pendidikan adalah proses dimana seseorang mengembangkan sifat dan bentukbentuk tingkah laku lainnya didalam masyarakat dimana ia hidup, proses sosial dimana orang dihadapkan pada pengaruh lingkungan yang terpilih dan terkontrol, sehingga ia dapat memperoleh atau mengalami perkembangan kemampuan sosial dan kemampuan individu yang optimal (Putri, 2020).

\section{Hubungan pekerjaan dengan kejadian covid -19}

Hasil penelitian menunjukkan responden yang tidak bekerja dengan terjadinya covid-19 sebanyak 18 orang (31,0\%). Hasil perhitungan menggunakan chi square didapatkan nilai $\mathrm{p}$ value $0,005 \quad(\mathrm{P}<0,05)$ menunjukkan ada hubungan pekerjaan dengan kejadian Covid di Desa Payung Kecamatan Weleri yang berarti $\mathrm{Ha}$ diterima Ho di tolak.mBekerja atau tidak bekerja menjadi penyebab terjadinya covid-19 
seperti penelitian yang dilakukan oleh Karunia (2020), menunjukkan bahwa responden yang terkonformasi covid19 sebagian besar tidak bekerja, yang tergolong tidak bekerja yaitu ibu rumah tangga dan lansia yang sudah pensiun.

Pekerjaan adalah kegiatan yang dilakukan responden untuk menghasilkan pendapatan dalam mencukupi kebutuhan hidup. Pekerjaan adalah aspek kelas social yang penting dan merupakan salah satu indikator terbaik untuk mengetahui cara hidup seseorang. Pekerjaan yang beresiko yang cenderung berkumpul dengan orang lain, memungkinkan terjadinya penularan Covid19 (Khasanah et al., 2020)

Menurut Dr. Franz Von Magnis di dalam (Anoraga, 2009), pekerjaan adalah kegiatan yang direncanakan. Sedangkan Hegel di dalam (Anoraga, 2009) menambahkan bahwa inti pekerjaan adalah kesadaran manusia. Kerja merupakan sesuatu yang dikeluarkan oleh seseorang sebagai profesi, sengaja dilakukan untuk mendapatkan penghasilan. Kerja dapat juga di artikan sebagai pengeluaran energi untuk kegiatan yang dibutuhkan oleh seseorang untuk mencapai tujuan tertentu.

\section{KESIMPULAN}

\section{Simpulan}

Mayoritas responden berusia antara 40-60 tahun sebanyak 32 (55,2\%), berjenis kelamin perempuan sebanyak 30 (51,7\%), pendidikan SD sebanyak 26 (44,8\%) dan tidak bekerja sebanyak 26 (44,8\%) Mayoritas responden tidak terkonfirmasi covid-19 sebanyak 30 $(51,7 \%)$ dan sebagian kecil terkonfirmasi covid-19 sebanyak 28 (48,3\%), ada hubungan usia, jenis kelamin, pendidikan dan pekerjaan dengan kejadian Covid -19

\section{Saran}

Petugas kesehatan diharapkan dapat memberikan edukasi/penyuluhan kesehatan tentang pentinya kepatuhan protokoler covid 19, sehingga dapat lebih meningkatkan pengetahuan pasien tentang covid-19 sehingga dapat meningkatkan kesadaran masyarakat dalam menerapakan $3 \mathrm{M}$ sehingga angka kejadian covid-19 dapat diturunkan

\section{UCAPAN TERIMAKASIH}

Pada kesempatan ini, peneliti ingin mengucapkan terima kasih kepada berbagai pihak yang telah membantu terwujudnya penelitian ini : 
1. Ketua Sekolah Tinggi Ilmu Kesehatan Muhammadiyah Kendal

2. Ketua Lembaga Penelitian dan Pengabdian Sekolah Tinggi Ilmu Kesehatan

\section{DAFTAR PUSTAKA}

Anoraga. (2009). Psikologi Kerja Jakarta : Rineka Cipta.

Chatterjee, P., Anand, T., Singh, K., Rasaily, R., Singh, R., Das, S., Singh, H., Praharaj, I., Gangakhedkar, R., Bhargava, B., \& Panda, S. (2020). Healthcare workers \& SARS-CoV-2 infection in India: A case-control investigation in the time of COVID19. Indian Journal of Medical Research. https://doi.org/10.4103/ijmr.IJMR_ 2234_20

Deng, L., Li, C., Zeng, Q., Liu, X., Li, X., Zhang, H., Hong, Z., \& Xia, J. (2020). Arbidol combined with $\mathrm{LPV} / \mathrm{r}$ versus $\mathrm{LPV} / \mathrm{r}$ alone against Corona Virus Disease 2019: A retrospective cohort study. Journal of Infection. https://doi.org/10.1016/j.jinf.2020.0 3.002

Diva Putra, A. I. Y., Pratiwi, M. S. A., Yani, M. V. W., Gunawan, G. R. D.,
Ganesha, G. M., Evelyn Aminawati, A. M. A., Aryana, I. P. G. D. W., \& Suryawati, I. G. A. A. (2020). Gambaran Karakteristik Pengetahuan, Sikap dan Perilaku Risiko Covid-19 Dalam Kerangka Desa Adat di Desa Gulingan, Mengwi, Bali. Jurnal Kesehatan Andalas, $\quad 9(3)$, 313. https://doi.org/10.25077/jka.v9i3.14 02

Jakobsson, J., Malm, C., Furberg, M., Ekelund, U., \& Svensson, M. (2020). Physical Activity During the Coronavirus

(COVID-19)

Pandemic: Prevention of a Decline in Metabolic and Immunological Functions. Frontiers in Sports and Active Living. https://doi.org/10.3389/fspor.2020.0 0057

Keliat et al. (2015). Keperawatan Kesehatan Jiwa Komunitas CMHN (Basic Course). E-Journal Keperawatan (EKP).

Kementrian Kesehatan RI. (2020). Situasi Terkini Perkembangan Novel Coronavirus (COVID-19) 19 November 2020. In Kementrian Kesehatan RI.

Khasanah, D. R. A. U., Pramudibyanto, H., \& Widuroyekti, B. (2020). 
Pendidikan Dalam Masa Pandemi Covid-19. Jurnal Sinestesia.

Lestari. (2020). Buku pedoman peanganan pasien kritis covid-19. Versi 1.

Mujani, S., \& Irvani, D. (2020). Sikap dan Perilaku Warga terhadap Kebijakan Penanganan Wabah Covid-19. Politika: Jurnal Ilmu Politik. https://doi.org/10.14710/politika.11. 2.2020.219-238

Nashrullah. (2020). Dampak Terjadinya Corona Virus.

Notoatmodjo. (2012). Promosi Kesehatan \& Ilmu Perilaku. Jakarta: Rineka Cipta.

Pratama, R. E., \& Mulyati, S. (2020). Pembelajaran Daring dan Luring pada Masa Pandemi Covid-19. Gagasan Pendidikan Indonesia, 1(2),

https://doi.org/10.30870/gpi.v1i2.94 05

Putra, A. I. Y. D., Pratiwi, Made Sindy AstriYani, M. V. W., Danang, G. R., Gunawan, Ganesha, Ghaniy Muhammad Aminawati, Agnes Maria Aprilia EvelynWibhawa, I. P. G. D., Aryana, \& Suryawati, I. G. A. A. (2020). Gambaran Karakteristik Pengetahuan, Sikap dan Perilaku Risiko Covid-19 Dalam Kerangka
Desa Adat di Desa Gulingan, Mengwi, Bali. Jurnal Kesehatan Andalas.

Putri, V. D. (2020). Layanan Bimbingan dan Konseling Daring Selama Masa Pandemi COVID-19. Jurnal Bimbingan Konseling Pendidikan Islam.

Rahayu Oktavia Asy'ari. (2020). Makalah Bahasa Indonesia Pengertian Covid-19 Dan Bentuk Partisipasi Dalam Memerangi Nya. Makalah Covid 19.

Rosyanti, L., \& Hadi, I. (2020). Dampak Psikologis dalam Perawatan dan Layanan Kesehatan Pasien. Jurnal Penelitian Informasi Kesehatan.

Sitepu, Y. R. B., \& Simanungkalit, J. N. (2021). Tingkat Stres Perawat Terkait Isu Covid-19. Jurnal Penelitian Perawat Profesional, 3 nomor 2(Mei), 287-294.

Suni, N. S. P. (2020). Kesiapsiagaan Indonesia Menghadapi Potensi Penyebaran Corona. Pusat Penelitian Badan Keahlian DPR RI. Susilo. (2020). Corona Virus Disease 2019: Tinjauan Literatur Terkini Coronavirus Desease 2019 : Review Of Current Literatures.

Susilo, A., Rumende, C. M., Pitoyo, C. W., Santoso, W. D., Yulianti, M., 
Herikurniawan, H., Sinto, R., Singh, G., Nainggolan, L., Nelwan, E. J., Chen, L. K., Widhani, A., Wijaya, E., Wicaksana, B., Maksum, M., Annisa, F., Jasirwan, C. O. M., \& Yunihastuti, E. (2020). Coronavirus Disease 2019: Tinjauan Literatur Terkini. Jurnal Penyakit Dalam Indonesia.

https://doi.org/10.7454/jpdi.v7i1.41 5

Varghese, G., John, R., Manesh, A., Karthik, R., \& Abraham, O. (2020). Clinical management of COVID-19. In Indian Journal of Medical Research.

https://doi.org/10.4103/ijmr.IJMR 957_20

WHO. (2020). Anjuran mengenai penggunaan masker dalam konteks COVID-19. World Health Organization.

World Health Organization. (2020).

Novel Coronavirus (COVID-19)

Situation. WHO (June 11).

Wu \& McGoogan. (2020). WHO Coronavirus Disease (COVID-19)

Dashboard. Bangladesh Physiotherapy Journal.

https://doi.org/10.46945/bpj.10.1.03 .01

Yuliana. (2020). Corona virus diseases
(Covid -19); Sebuah tinjauan literatur. Wellness and Healthy Magazine. 